\title{
A Second brood in Canada Geese Branta canadensis?
}

\author{
Andrahäckning hos kanadagås Branta canadensis?
}

\author{
CHARLOTTE BERG \& HENRIK LERNER
}

Abstract

\begin{abstract}
Canada Geese Branta canadensis do normally not produce more than one clutch per year. On the island of Nidingen off the west coast of Sweden a pair of Canada Geese successfully reared one early brood of young in the spring ( 2 and 8 young respectively in 2011 and 2012). Apparently the same pair in both years, approximately 35-40 days after hatching the first brood, laid a second batch of eggs in the same nest. In this paper, these events are described in detail and alternative explanations are discussed. No indications of adoption of young or change of partner in the couple could be identified; hence the hypothesis of a true second brood remains strong.
\end{abstract}

Charlotte Berg, Department of Animal Environment and Health, Swedish University of Agricultural Sciences, PO Box 234, SE-532 23 Skara, Sweden,

e-mail lotta.berg@slu.se

Henrik Lerner, Department of Health Care Sciences, Ersta Sköndal University College, PO Box 11189, SE10061 Stockholm, Sweden, e-mailhenrik.lerner@esh.se

Received 14 January 2014, Accepted 20 March 2014, Editor: J. Waldenström

\section{Introduction}

Generally amongst geese and other waterfowl, a second breeding attempt might occur when a clutch is lost early in the nesting period within temperate populations (West et al. 1986). In wild arctic populations no re-nesting has been found to occur (Cramp \& Simmons 1977, Ogilvie 1978). No second broods are known in geese (Cramp \& Simmons 1977), with the exception of one record in wild Canada Geese Branta canadensis (Brakhage 1985) and a few cases in semi-captive Barnacle Geese Branta leucopsis (West et al. 1986). The reasons for not laying a second brood are likely twofold. First, the female loses substantial body weight (in the form of fat, protein and other nutrient stores) during egg-laying and incubation and, second, regaining weight takes time and may delay the re-initiation of breeding too late in the season (Ogilvie 1978, Alisauskas \& Ankney 1992). There are also hormonal changes in the adult birds during rearing of the first goslings that would prohibit renesting (West et al. 1986, Bluhm 1992). Suggested explanations in the case of the wild Canada Geese were a prolonged nesting season, involving resident birds which did not invest energy in migra- tion and a sufficiency of food supplies (Brakhage 1985). Here, we present data from what seems to be a case of a second clutch in Canada Geese, thus questioning the established theory, which claims that the species does not lay a second clutch in temperate climates.

The Canada Goose was introduced to Sweden about 1930 (Madsen et al. 1999, Kampe-Persson 2010, Ottosson et al. 2012). Most individuals seem to belong to one of the larger races, although there is still some uncertainty as to their origin (Sjöberg 1993). The breeding population in Sweden is approximately 17000 pairs (Ottosson et al. 2012, see also Kampe-Persson 2010) and increasing (Fox et al. 2010). In June 2011, staff at the Nidingen bird ringing station noticed that a pair of Canada Geese, which had hatched two young previously during the same season, was incubating a second brood. The following year, i.e. 2012, the same phenomenon was noticed again, when it was decided to gather information to establish whether this was actually a true case of a second brood in Canada Geese or related to adoption of young or involved exchange of one of the responsible parents of the original pair. 


\section{Materials and methods}

The Ornithological Society of Gothenburg runs the bird ringing station on the small uninhabited island of Nidingen approximately $8 \mathrm{~km}$ off the coast of Halland, Sweden (N $57^{\circ} 18.166$ '; E $11^{\circ} 54.123^{\prime}$ ). The island is a nature reserve and visitors are allowed only onto restricted areas during the breeding season. Bird ringing staff stationed on the island continuously from March to November catch and ring birds and report daily bird species abundance via the internet reporting system Artportalen (http://www.artportalen.se/birds/). Observations include breeding status of the birds involved, ranging from "observed in a suitable breeding environment" to "nest with eggs or young observed", with free text comments and explanatory notes added to the records. There is also an internet-based daily diary publication system included in Artportalen, where the station manager publishes short summaries of the activities and events of the day. Records relating to Canada Geese on the island of Nidingen during the breeding season (here limited to mid March - mid July) in 2011 and 2012 were compiled from Artportalen and the Nidingen diary, and the results described and discussed below are based on information from these records.

\section{Results}

From 13 March until 13 August 2011, Canada Geese were recorded on the island almost every day. During April, what appeared to be 4 pairs using 4 different nesting sites were recorded using distinctively discrete home ranges with specific nest sites identified (the West Point pair, the Hollow pair, the Eastern Groove pair and the Vicar's Grave pair) (Figure 1). On 2 April the West Point pair was noted on the breeding ground and 3 days later, it was reported that the male in the West Point pair was wearing a ring on his left leg. At that time there were 6 eggs in the nest. By 7 April, the Vicar's Grave pair's nest had been predated and was abandoned, whereas the West Point pair had 7 eggs in their nest. On 7 May, the West Point pair had hatched 2 young, which were frequently reported and by 7 June were the only Canada Geese hatched on the island. No details about the other 2 nests were mentioned, but from the absence of brood records it can be assumed that these eggs were not hatched.

On 8 June the West Point pair was reported with a second batch of 3 eggs in the same nest with a fourth laid by 11 June, while the male continued accompanying the young and guarding the incubating female, showing aggression towards approaching humans. Photographs from 19 June show the female standing over the 4 eggs in the nest, with the male standing next to her together with 2 well grown young (Figure 2 ). The male clearly bears a metal ring on his left leg, although the female is not ringed.

By 27 June, the West Point female was reported as not having been incubating the nest for several

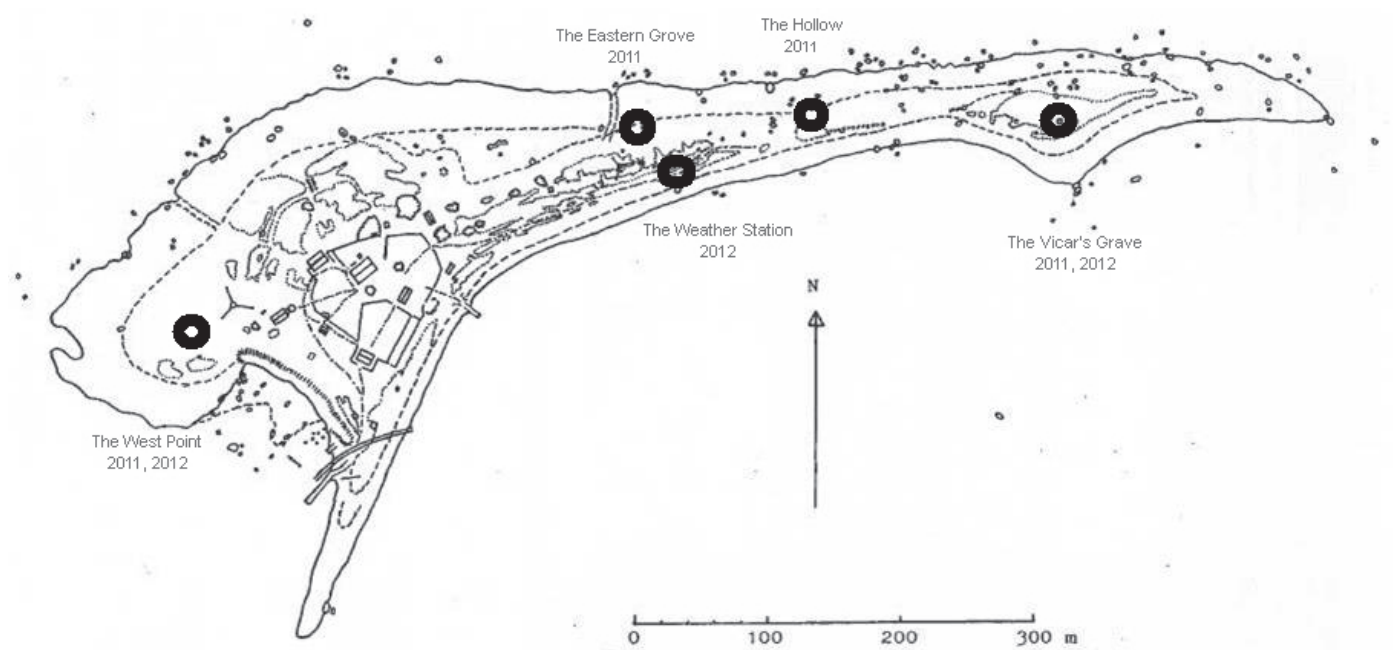

Figure 1. Map of the island of Nidingen, indicating Canada Goose nest locations in 2011 and 2012 respectively. Original map produced by U. Unger.

Karta over ön Nidingen, som visar var kanadagässens bon var belägna år 2011 respektive 2012. Originalkarta framtagen av $U$. Unger. 


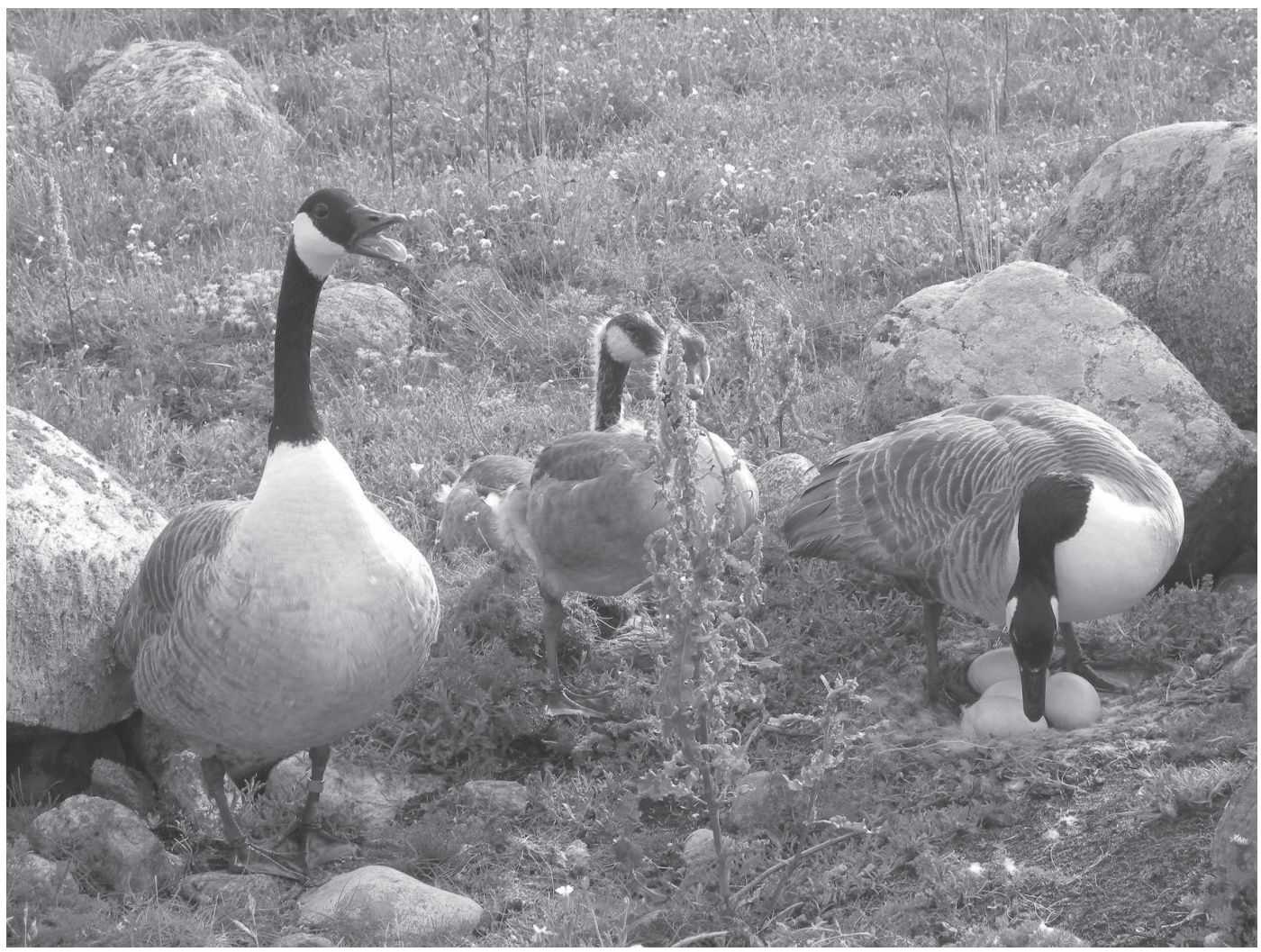

Figure 2. Photograph taken on 19 June 2011, showing the pair of Canada Geese described in this paper, the two young and the four eggs. Photo: C. Berg

Fotografi taget den 19 juni 2011, som visar det kanadagåspar som beskrivs i denna artikel, deras två ungar och de fyra äggen. Foto: C. Berg.

days, and when bird station staff approached the nest is was empty, presumably as a result of predation by gulls or crows. The pair and 2 large goslings were seen at sea close to the West Point area on 28 June with no reports of Canada Geese breeding activities after that date.

During 2012, a similar pattern was observed. Canada Geese were recorded present from 11 March until 5 August. During April 6 separate pairs were seen, but only 3 nest sites identified (the West Point pair, the Weather Station pair and The Vicar's Grave pair) (Figure 1). The West Point pair (the male again ringed on his left leg with an unmarked female) was recorded present and incubating 6 eggs on 29 March, rising to 8 on 31 March. On 29 April these eggs hatched eight young which were regularly reported through June in the West Point area and adjacent areas. On 7 May the Weather Station pair was recorded incubating and an unmarked pair was seen on West Point. The Weather
Station female was caught and ringed (right leg) on 8 May when the Vicar's Grave pair's nest was found predated. It was not known if there were more active Canada Geese nests on the island, but the Weather Station nest hatched four young on 12 May. From 28 May to 9 July, these 2 families of 3 and 8 goslings were continuously reported.

On 11 June, the unmarked West Point female (assumed by the staff to be the same one throughout the entire season) was incubating 6 eggs in the same nest as the previous clutch, when an unmarked bird was associating, but not in an aggressive manner. The male with a ring on his left leg was seen together with the eight large young from the previous clutch. On 14 June, the female was still incubating the eggs, but by 16 June, it was recorded that she had been absent for two days and was back with the male and the 8 large young on the northern shore of the island.

On 10 July, 1 dead gosling was found at the 
Kausan beach, and 1 was reported as diseased on 12 July. However, these 2 young did not belong to the West Point pair, as their litter of 8 large young was still recorded as intact on 12 July.

The interval between the hatching of the first clutch and the first eggs laid in the second clutch was, based on the Artportalen records, estimated to 35-40 days for both years.

\section{Discussion}

These records strongly suggest this female Canada Goose laid a second clutch, contrary to the established view that geese never lay a second clutch (Cramp \& Simmons 1977) if the first clutch is reared successfully. Whilst we cannot prove the identity of the female conclusively, the presence of the same defending male (bearing a ring) and the use of the same nest in the same area in two consecutive years is suggestive this was the case. This implies that despite the substantial body weight loss during egg-laying and incubation (Ogilvie 1978), geese in the temperate areas may be able to recoup stores in time to lay a second clutch in the wild. Canada Geese do not overwinter on Nidingen, but stay on the island during the entire nesting season which indicates sufficient food resources.

The first published record of a second clutch for individually marked Canada Geese (Brakhage 1985) was also from the temperate zone (Missouri, USA). The eggs were laid earlier in the season, probably due to the more southern location. In 1983 the first clutch of 10 eggs resulted in one gosling. When the female laid the first egg in the second clutch 24 days later the gosling was no longer with the pair. The second clutch contained 9 eggs resulting in one gosling. From the semi-captive flock of 200 Barnacle Geese at the Wildfowl Trust in southern England, five different pairs were reported producing second clutches (West et al. 1986). The authors in that case suggested that this was a result of the superabundant of food supply, as the flock was fed grain and a high protein supplement during the breeding season.

The island of Nidingen lies far from the coast and from other islands, with very little exchange of geese during the breeding season, except for geese moulting in the area. For this reason, we are confident that the West Point male was involved in the first, successful hatching of broods in 2011 and 2012 and was also involved in the second brood, as this male bird was the only ringed Canada Goose on the island during the season in question during 2011, and the only bird ringed on the left leg dur- ing 2012. Unfortunately, we cannot confirm the identity of the female as being responsible for both broods in both years. The established theory mainly focuses on the constraints imposed by female body condition that limit her ability to invest in a second clutch. The male suffers no such demands and therefore is more able to invest in a second clutch because he is not producing eggs, but still creates conflicts between his investment in mate guarding at the nest and brood rearing which is normally undertaken by both parents. There were no indications that the broods of two and eight goslings could have been hatched by another pair in another nest, and then adopted by the West Point pair. Although not theoretically impossible, this seems highly unlikely as no other pair was seen nesting that early in the season either year. The distance to the nearest of the other Canada Goose nests was estimated to 350 meters (2011) and 420 meters (2012).

In both years, the second clutch failed to hatch. Based on the recorded information, we hypothesize that the eggs were predated after being abandoned by the female. This study shows that second broods may occur very rarely in short distance migratory temperate nesting Canada Geese, in contrast to conventional theories about breeding in northern geese. However, individual marking (preferably neck-banding, which can be read from a distance), close observation and DNA analysis of parents and young are necessary to establish the parentoffspring-sibling relationships involved (see Black et al. 2007 for a presentation on such studies). The study of isolated island populations might facilitate this.

\section{Acknowledgements}

The authors would like to acknowledge the valuable input given by the Nidingen bird ringing station managers, in person and via the Artportalen reporting system. A special thanks to Uno Unger for supplying the Nidingen map. Valuable comments on an earlier version of this paper were given by Jouke Prop, University of Groningen, to whom we would like to express our gratitude. We would also like to thank the anonymous referees of Ornis Svecica.

\section{References}

Alisauskas, R. T. \& Ankney, C. D. 1992. The cost of egg laying and its relationship to nutrient reserves in waterfowl. Pp. 30-61 in Ecology and Management of Breeding Waterfowl (Batt, B. D. J., Afton, A. D., Anderson, M. G., Ankney, C. D., Johnson, D. H., J.A. Kadlec, J. A. \& Krapu, 
G. L. eds.). University of Minnesota Press, Minneapolis.

Black, J. M., Prop, J. \& Larsson, K. 2007. Wild Goose Dilemmas. Branta Press. Groningen, The Netherlands.

Bluhm, C. K. 1992. Environmental and endocrine control of waterfowl reproduction. Pp. 323-365 in Ecology and Management of Breeding Waterfowl (Batt, B. D. J., Afton, A. D., Anderson, M. G., Ankney, C. D., Johnson, D. H., J.A. Kadlec, J. A. \& Krapu, G. L. eds.). University of Minnesota Press, Minneapolis.

Brakhage, D. H. 1985. A second brood by Canada geese. Wilson Bulletin 97(3): 387-388.

Cramp, S. \& Simmons, K. E. L. (eds) 1977. Handbook of the Birds of Europe, the Middle East and North Africa. The Birds of the Western Palearctic. Volume 1. Ostrich to Ducks. Oxford University Press. Oxford.

Fox, A. D., Ebbinge, B. S., Mitchell, C., Heinicke, T., Aarvak, T., Colhoun, K., Clausen, P., Dereliev, S., Faragó, S., Koffijberg, K., Kruckenberg, H., Loonen, M. J. E., Madsen, J., Mooij, J., Musil, P., Nilsson, L., Pihl, S. \& van der Jeugd, H. 2010. Current estimates of goose population sizes in Western Europe, a gap analysis and an assessment of trends. Ornis Svecica 20: 115-127.

Kampe-Persson, H. 2010. Naturalised geese in Europe. Ornis Svecica 20: 155-173.

Madsen, J., Cracknell, G. \& Fox, T. (eds) 1999. Goose populations of the Western Palearctic. A review of status and distribution. Wetlands International Publication No. 48. Wetlands International. Wageningen, The Netherlands. National Environmental Research Institute. Rönde, Denmark.

Ogilvie, M. A. 1978. Wild Geese. T and AD Poyser. Berkhamsted.

Ottosson, U., Ottvall, R., Elmberg, J., Green, M., Gustafsson, R., Haas, F., Holmqvist, N., Lindström, Å., Nilsson, L., Svensson, M., Svensson, S. \& Tjernberg, M. 2012. Fåglarna i Sverige - antal och förekomst. Sveriges Ornitologiska Förening. Halmstad.

Sjöberg, G. 1993. Nesting and Migration in the Introduced Canada Goose in Sweden. Ph.D. thesis, Dept. of Animal Ecology, Umeå University, Sweden.

West, J., Black, J. M., Nugent, M.J., \& Owen, M. 1986. Second-brooding in semi-captive Barnacle Geese. Wildfowl 37: 51-54.

\section{Sammanfattning}

Generellt gäller hos gäss och andra simfåglar i tempererat klimat att en andra kull kan läggas om den första omgången ägg/ungar förloras tidigt under häckningssäsongen (West et al. 1986). Hos vilda arktiska gäss har omläggning däremot inte kunnat påvisas (Cramp \& Simmons 1977, Ogilvie 1978). Andrakullar förekommer normalt inte hos gäss (Cramp \& Simmons 1977), med undantag av några exempel gällande vitkindade gäss Branta leucopsis som hållits i parker (West et al. 1986). Orsaken till detta är tudelad. Dels förlorar honan förhållandevis mycket i vikt under ruvningsperioden, och det tar tid att återfå denna vikt efteråt, och då är det alltför sent på säsongen (Ogilvie 1978, Alisauskas \& Ankney 1992). De hormonella förändringar som uppstår hos de vuxna fåglarna skulle också kunna medverka till att förhindra omläggning (West et al. 1986, Bluhm 1992). Dock har ett fall av andrakull hos kanadagås Branta canadensis rapporterats tidigare (Brakhage 1985). Föreslagna förklaringar i det fallet var lång häckningssäsong, icke-migrerande fåglar som därför inte förlorar energi i samband med flytt, samt god födotillgång. Den allmänt vedertagna uppfattningen torde dock likväl vara att kanadagäss egentligen inte kan få mer än en kull gässlingar per år.

På ön Nidingen, belägen ungefär $8 \mathrm{~km}$ utanför Hallands nordligaste kust (N $57^{\circ} 18.166^{\prime}$; E $11^{\circ}$ 54.123'), tycks dock 1 par kanadagäss framgångsrikt ha fött upp en tidig kull ungar på våren ( 2 respektive 8 ungar år 2011 respektive 2012). Samma par har sedan, ungefär 35-40 dagar efter det att den första kullen kläckts, lagt en andra omgång ägg $\mathrm{i}$ samma bo (Figur 1). På ön ligger Nidingens fågelstation (Göteborgs Ornitologiska Förening), vilken är bemannad från mars till november. Nidingen är naturreservat och besökare får under häckningstid endast beträda en mycket begränsad del av ön. Fågelstationens personal gör dagligen anteckningar och rapporteringar både genom artvisa rapporter på Artportalen och i form av mer allmänt hållna dagboksanteckningar i samma forum. Dessa noteringar och rapporter har utgjort det huvudsakliga underlaget till denna artikel.

Eftersom ön är lättövervakad och endast ett fåtal par häckar på ön (Figur 1) är data relativt säkra. Då inga tecken på adoption av andras ungar eller byte av partner kunnat ses kvarstår en stark hypotes om att det rör sig om äkta andrahäckningar.

De publicerade fallen av andrahäckning hos Branta-gäss har samtliga inträffat i tempererade områden (Brakhage 1985, West et al. 1986, den här studien). Tänkbara förklaringar till att en andrakull är möjlig är att tempererade områden till skillnad från arktiska uppvisar en längre häckningssäsong samt god tillgång till föda. För att i framtiden kunna säkerställa andrakullar hos gäss torde det vara lämpligt att studera dem i tempererade områden, med individuell märkning kombinerat med DNAanalyser. 